\title{
Assessment of land degradation and implications on agricultural land in Qalyubia Governorate, Egypt
}

\author{
W. A. M. Abdel Kawy ${ }^{1}$ and Kh. M. Darwish ${ }^{2^{*}}$ (D)
}

\begin{abstract}
Background: Land degradation considers as a phenomena or more that decrease the current and/or the potential soil capability to produce goods. It signifies a regression from a higher to lower state, owing to descend in land capability, productivity, and decline of biodiversity. This study is an attempt to address the complexity of land degradation issue, particularly in the targeted farming irrigated fields, Qalyubia Governorate, Egypt. It aims to assess and observe degradation hazard through satellite image analyze, model trends of degradation, and generate a change detection hazard map for the investigated area.

Results: The maximum likelihood supervised classification tool and post classification change detection technique were implemented for monitoring changes in land qualities. Land degradation indicator data layers were summarized into the metrological data, ground truth, vegetation cover, and the applied land management practices. The Modified Global Assessment of Soil Degradation GLASOD model was adapted to model land degradation, specify its action in term of degradation degree, relative extent, severity level, and causative factors. Land degradation processes were evaluated in the delineated mapping units. The result indicated that the studied areas are considered as quite unstable in term of ecosystem due to active degradation resulting from aridity phenomena, soil properties, and improper farm management.
\end{abstract}

Conclusion: The most active land degradation processes are assessment of salinization, waterlogging, alkalization, and soil compaction.

Keywords: Land degradation, Degradation hazard, Land qualities, Qalyubia governorate, Arid land

\section{Introduction}

The United Nations Convention to Combat Desertification (UNCCD) recognizes land degradation as one of the most noticeable environmental concerns of recent times (UNCCD 1994, 2002). According to Baylis et al. 2012 and UNCCD 2013, they reported the sequences as a result of land degradation processes; nearly $40-75 \%$ of the world's agricultural land's productivity is reduced.

Land degradation is often described as substantial decrease in the biological productivity of land system, due to natural events exaggerated by anthropogenic activities (Johnson and Lewis 2007). Land degradation in dry land

\footnotetext{
* Correspondence: kdarwish@hotmail.com; kdarwish@srtacity.sci.eg ${ }^{2}$ Land and Water Technologies Department, Arid Lands Cultivation Research Institute, City of Scientific Research and Technological Applications (SRTA-City), Borg Al-Arab, Alexandria, Egypt

Full list of author information is available at the end of the article
}

is often termed as desertification (Dregn 2002). Most forms of land degradation are man-made problems. Although there are some physical environmental factors involved, but misuse is an important factor. Poor land management with the intensification of agriculture practices accelerates the rate of land degradation (Wim and El-Hadji 2002). Food supply situation will be worse in the future, if the current tendency of land degradation did not change drastically. In Egypt, land resources degradation is the main limitation to the agricultural sector development, where the ratio between land resources and population rate is the most critical problem currently. In arid and semi-arid conditions, the salinization and/or alkalization as subsequent of water logging are the major land degradation processes in irrigated agriculture fields (Ayoub 1991; Dwivedi et al. 1999; El-Kassas 1999). 


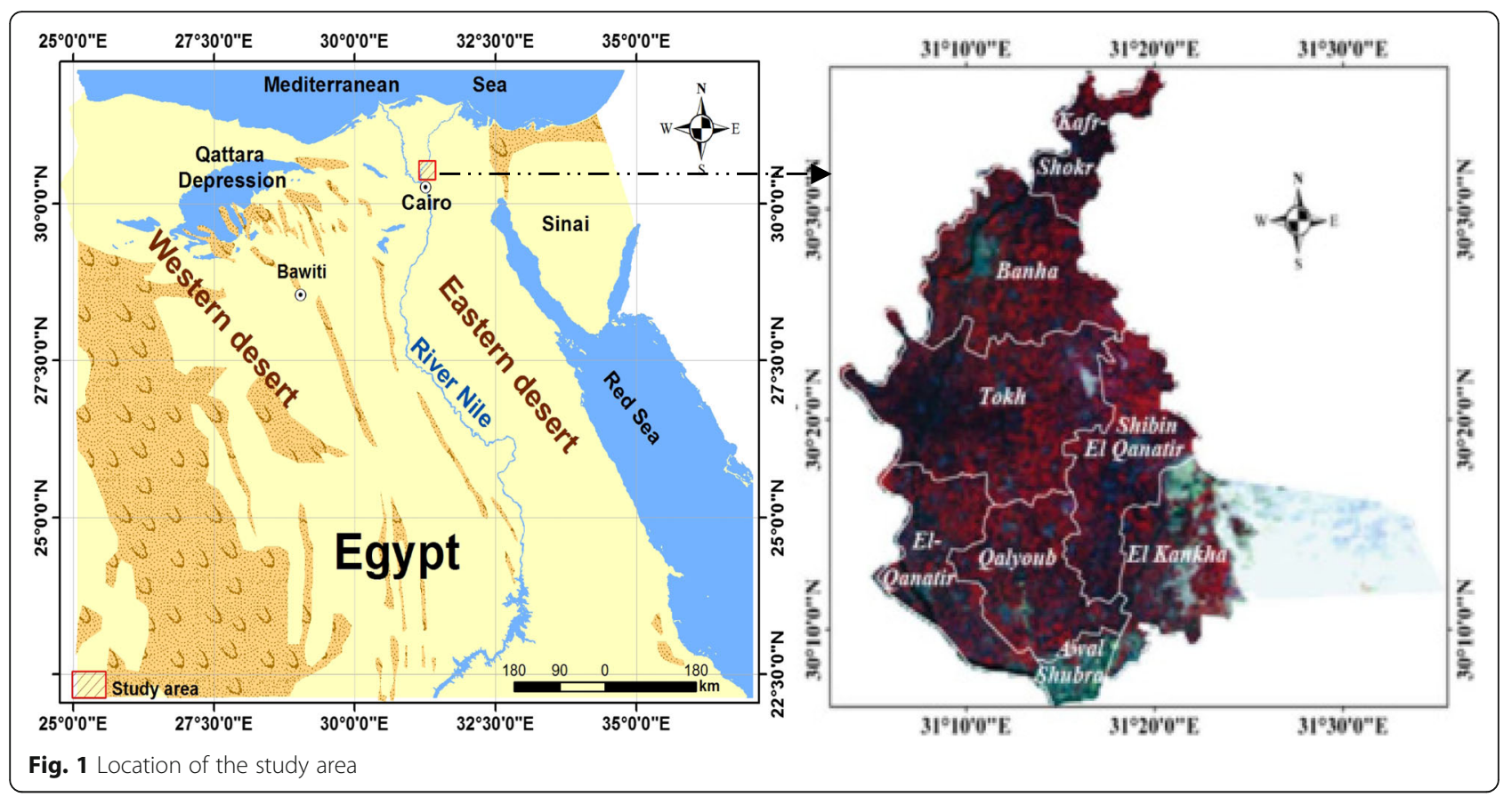

Normally, inter-relationship between land degradation and socioeconomic activities is a multi-layered and complex issue. Several multi-disciplinary approaches integrated with multiple data sources and methodologies to study the implications of land degradation are need of the hour. Monitoring and assessment of regional land degradation or restoration of land is very important so as to understand the dynamic trend of land degradation or restoration, providing better scientific prevention and environmental control (Sun et al. 2017). To address the gaining issue and a systematic understanding of the changes magnitude in land degradation at the temporal and regional scales, remote sensing and geographical information system (GIS) have been selected as the best utilities.

In the area under investigation, the current research aims to highlight various land degradation processes using a GIS platform and remote sensing (RS) data. Asses human-induced land degradation and evaluate loss of soil productivity, which is considered as a degradation factor meaningful to desertification caused by land mismanagement and human influence. Detection of land use/cover change technique that is used to monitor agricultural land among dates 1967-2017. The evaluation of soil capability lost.

\section{Study area}

Regionally, Qalubiya is one of the largest governorates, which is located in the eastern side of the River Nile. Officially, Qalubiya includes eight districts, and its capital town is called Banha. Mostly, the major activity is cultivation, where there is some existence of industrial zones.
The area under investigation incorporates a surface area of approximately 224,363 ac (90.8 ha). It is bounded between $30^{\circ} 06^{\prime} 11^{\prime \prime}$ and $30^{\circ} 36^{\prime} 36^{\prime \prime}$ North and $31^{\circ} 03^{\prime}$ $20^{\prime \prime}$ and $31^{\circ} 35^{\prime} 32^{\prime \prime}$ East Fig. 1. According to the Egyptian Meteorological Authority (2016), the study area falls in the arid zone, where the soil temperature regime could be defined as thermic and moisture regime is torric (Soil survey staff 2014).

Geologically, the area belongs to the late Pleistocene that represented by deposits of the neonile broke into Egypt, often in the earlier part of this age and by the deposits too that was accumulated during the recessional phases of the river. Through its history, the neonile in this massif has been continuously lowering its course at a rate of $1 \mathrm{~m} / 1000$ years (Said 1993).

\section{Material and methods Landform mapping}

Collection of data sources includes soil map of Egypt (ASRT 1982), topographic-sheets (scale 1:25,000), and a Landsat- 8 satellite image was used to cover the study area, which was acquired in August, 2016, with a path (176) and row (39) from the (USGS) Geologic Survey archive (http://earthexplorer.usgs.gov/) (Fig. 2). As an image preprocessing analysis, the image was calibrated to radiance using the inputs of image type, acquisition date, and time, then it was stretched using linear $2 \%$, smoothly filtered, and their histograms were matched (Lillesand and Kiefer 2007). Atmospheric correction was done, then images were mosaicked and geometrically rectified using ENVI 5.1 software (ITT 


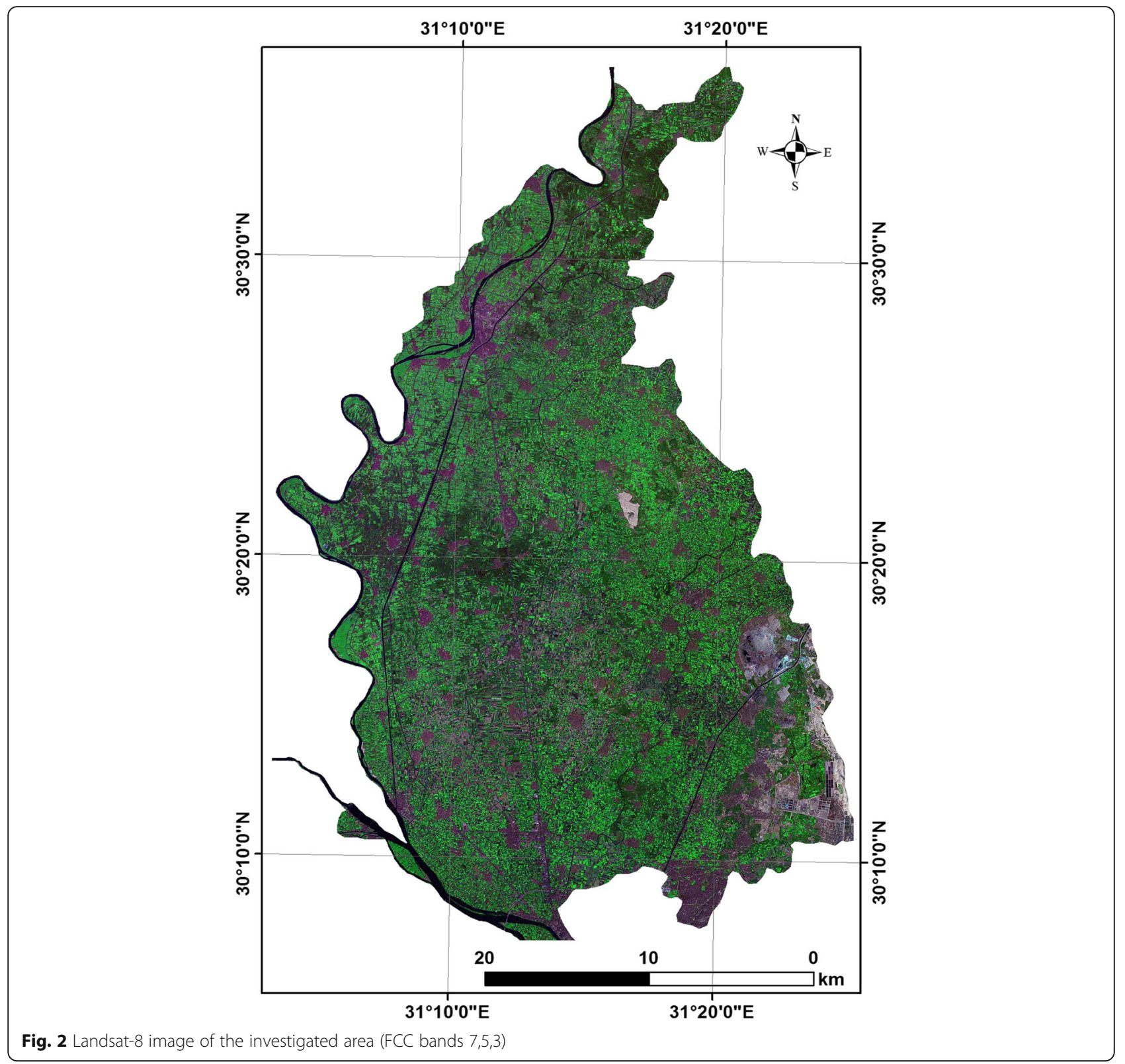

2009). High spatial resolution satellite data are needed for delineation of landform features, so the spatial resolution of Landsat-8 image was enhanced through merging process of the higher spatial resolution panchromatic data (band 8). This process is applied and resulting in multi-spectral data with high spatial resolution $(14.25 \mathrm{~m})$. The geomorphology layer was generated by the integration of contour lines extracted from the digital elevation data DEM that derived from topo sheets integrated with SRTM 1 arc second data and the enhanced Landsat-8 image using ENVI 5.1 software (Dobos et al. 2002). Physiographic map of the study area has been produced using physiographic analysis, then map legend was established according to Zink and Valenzuala (1990).

\section{Field work}

A total of 15 soil profiles were taken to represent different mapping units. The ground truth data, field survey, soil profile morphological and pedological investigations, and analytical data reveal the main characteristics of different land form map units.

\section{Laboratory analysis}

The field-collected representative soil samples were analyzed according to US Soil Survey Staff (2014). The collected soil samples and auger observations were first air dried, then ground gently, and sieved through 2-mm sieve, where the main physical and chemical properties were determined based on the laboratory routine 
Table 1 Rating for physical vulnerability

\begin{tabular}{llllll}
\hline Factor & Index & \multicolumn{3}{l}{ Class } & \\
\cline { 3 - 6 } & & Low & Moderate & High & Very high \\
\hline Climate & $\Sigma \mathrm{p}^{2} / \mathrm{p}-$ & $0-50$ & $50-500$ & $500-1000$ & $>1000$ \\
Soil & Slit\%/Clay\% & $<0.2$ & $0.2-0.3$ & $0.3-0.7$ & $>0.7$ \\
Topography & Slope \% & $0-2$ & $2-8$ & $>8$ & - \\
\hline
\end{tabular}

Adapted FAO (1978); $\mathrm{p}=$ monthly precipitation, $\mathrm{p}$ - $=$ annual precipitation

analysis procedures (Richard 1954; Page et al. 1982). Soil classification and taxonomy was done using Soil survey staff (2014). Worth to mention that the soil correlation between the physiographic and taxonomic units were designed in order to identify the major soil sets of the studied area, after Elberson and Catalan (1987). ArcGIS 10.3 was the main GIS platform used in this study.

\section{Land degradation status}

The conceptual framework applied to the work is based on a comparison study between the data extracted from the soil survey of El-Qalyubia governorate report RISW (1967), and the more recent ground truth data been done in 2017. In regard to the pedoloical, topography features, and climatic factors that are defined and described according to FAO/UNEP (1978, 1979) methodology for assessing soil degradation, the natural vulnerability for each soil profile was evaluated and confirmed with the physiographic units. The rating used is presented in Tables 1 and 2) and the soil degradation classed and rates are shown in Table 3. The status of soil degradation is an expression of the process severity. The severity of the processes is characterized by the degree in which the soil degraded and by the relative extent of the degraded area with in a delineated physiographic unit.

The degradation degree, relative extent, severity level, and causative factors were defined and modeled by using the Global Assessment of Soil Degradation (GLASOD) approach (UNEP 1991) as follows:

1- Degree of soil degradation: the criteria used to determine the degree of degradation is illustrated in Table 4.

2- Relative extent of the degradation type: due to the mapping complication of separating areas of

Table 2 Rating for chemical vulnerability

\begin{tabular}{|c|c|c|c|c|c|}
\hline \multirow[t]{2}{*}{ Factor } & \multirow[t]{2}{*}{ Index } & \multicolumn{4}{|l|}{ Class } \\
\hline & & Low & Moderate & High & Very high \\
\hline Climate & $\mathrm{PET} /(\mathrm{P}+\mathrm{Q}) 10$ & $<0.1$ & $0.1-0.3$ & $0.3-0.5$ & $>0.5$ \\
\hline Soil & Texture class & Clay & Silt & Sand & - \\
\hline Topography & Slope \% & $0-2$ & $2-8$ & $>8$ & - \\
\hline
\end{tabular}

Adapted after FAO (1978). PET potential evapo-transpiration, $p$ precipitation/ year, $Q$ irrigation water
Table 3 Soil degradation classes and rates

\begin{tabular}{lll}
\hline $\begin{array}{l}\text { Chemical } \\
\text { degradation }\end{array}$ & $\begin{array}{l}\text { Salinization (Cs) increase in } \\
(\mathrm{EC}) \text { per dS/m/year }\end{array}$ & $\begin{array}{l}\text { Alkalization (Ca) increase } \\
\text { in ESP\%/year }\end{array}$ \\
Non to slight & $<0.5$ & $<0.5$ \\
Moderate & $0.5-3$ & $0.5-3$ \\
High & $3-5$ & $3-7$ \\
Very high & $>5$ & $>7$ \\
Physical & Compaction/increase in & Water logging/increase \\
degradation & bulk density per $\mathrm{g} / \mathrm{cm}^{3} /$ year & in water table in $\mathrm{cm} /$ year \\
Non to slight & $<0.1$ & $<1$ \\
Moderate & $0.1-0.2$ & $1-3$ \\
High & $0.2-0.3$ & $3-5$ \\
Very high & $>0.3$ & $>5$
\end{tabular}

Adapted FAO (1979)

soil degradation individually, it was possible to estimate the relative extent of each type of soil degradation within the map unit. The following five categories are recognized:

- Infrequent: up to $5 \%$ of the unit is affected.

- 2-Common: $6-10 \%$ of the unit is affected.

- 3-Frequent: $11-25 \%$ of the unit is affected.

- 4-Very frequent: $26-50 \%$ of the unit is affected.

- 5-Dominate over: $50 \%$ of the unit is affected.

3- The severity level of soil degradation: the severity level is indicated by combination of the degree and relative extent as shown in Table 5.

4- Causative factors: causative factors of the different land degradation types were identified in the field and also collected from the available technical reports.

\section{Results}

Physiographic and soil map

Physiographic map of the investigated area has been generated using physiographic analysis (Zinck and Valenzuala 1990) by combining Landsat 8 satellite image and Digital Elevation Model DEM derived from topographic maps in integration with the Shuttle Radar Topography Mission SRTM data. According to the soil profile morphological description, sample analysis, and

Table 4 Criteria used to determine the degree of degradation types

\begin{tabular}{|c|c|c|c|c|c|c|}
\hline \multirow{2}{*}{$\begin{array}{l}\text { Critical/ } \\
\text { hazard type }\end{array}$} & \multirow[t]{2}{*}{ Indicator } & \multirow[t]{2}{*}{ Unit } & \multicolumn{4}{|l|}{ Class } \\
\hline & & & Low & Moderate & High & $\begin{array}{l}\text { Very } \\
\text { high }\end{array}$ \\
\hline Salinization & $\mathrm{EC}$ & $\mathrm{dS} / \mathrm{m}$ & 4 & $4-8$ & $8-16$ & $>16$ \\
\hline Alkalization & ESP & $\%$ & 10 & $10-15$ & $15-30$ & $>30$ \\
\hline Compaction & $\begin{array}{l}\text { Bulk } \\
\text { density }\end{array}$ & $\begin{array}{l}\mathrm{g} / \\
\mathrm{Cm}\end{array}$ & 1.2 & $1.2-1.4$ & $1.4-1.6$ & $>1.6$ \\
\hline $\begin{array}{l}\text { Water } \\
\text { logging }\end{array}$ & Water table & $\mathrm{Cm}$ & 150 & $150-100$ & $\begin{array}{l}100- \\
50\end{array}$ & $<50$ \\
\hline
\end{tabular}


Table 5 The severity level of soil degradation

\begin{tabular}{|l|c|c|c|c|c|}
\hline \multirow{2}{*}{\multicolumn{1}{|c|}{ Degree of soil degradation }} & \multicolumn{5}{c|}{ Relative extent (\%) } \\
\cline { 2 - 6 } & $\mathbf{0 - 5}$ & $\mathbf{6 - 1 1}$ & $\mathbf{1 1 - 2 5}$ & $\mathbf{2 6 - 5 0}$ & $\mathbf{5 0 - 1 0 0}$ \\
\hline Slight & 1.1 & 1.2 & 1.3 & 1.4 & 1.5 \\
\hline Moderate & 2.1 & 2.2 & 2.3 & 2.4 & 2.5 \\
\hline Strong & 3.1 & 3.2 & 3.3 & 3.4 & 3.5 \\
\hline Extreme & 4.1 & 4.2 & 4.3 & 4.4 & 4.5 \\
\hline
\end{tabular}

The severity classed

\begin{tabular}{|c|c|c|c|}
\hline Low & Moderate & High & Very high \\
\hline
\end{tabular}

classification, soils were classified into two main orders (Aridisols and Entisols) and ten great groups were identified as shown in Fig. 3 and Table 6. The obtained physiography map revealed that the island is occupied $0.59 \%$ of the investigated area, while the sub-island $1.12 \%$ and the levee $1.44 \%$. The over flow mantle is occupied 14.26, the over flow basin $27.17 \%$, the decantation basin $48.34 \%$, the turtle backs $0.27 \%$, and the sequence of river terraces form $6.81 \%$.
According to the soil taxonomy classification (Soil Survey Staff 2014), studied soils could be classified as:

- I, Typic Torripsamment (cons.)-SI, Typic

Torripsamment (cons.)

- L, Typic Torripsamment (cons.)-O.M, Typic

Torrifluvent (cons.)

- O.M, Typic Paleargids (Assoc.)-O.B, Vertic

Torrifluvent (cons.)

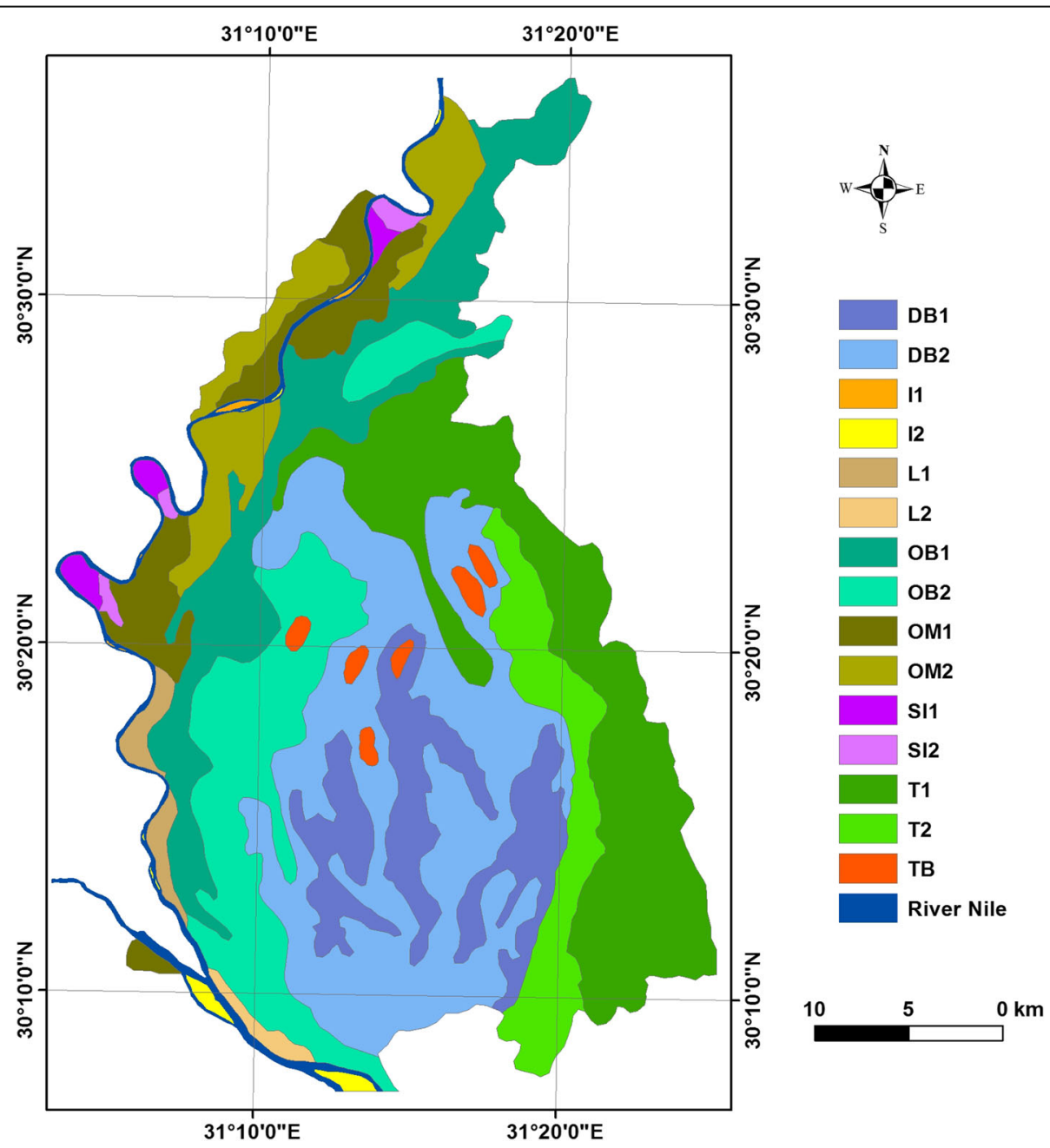

Fig. 3 Physiography and soil map of Qalyubia Governorate 
Table 6 Physiographic and soil map legend of the investigated area

\begin{tabular}{|c|c|c|c|c|c|c|c|}
\hline Landscape & Relief & Lithology/origin & Land form & $\begin{array}{l}\text { Mapping } \\
\text { unit }\end{array}$ & $\begin{array}{l}\text { Profile } \\
\text { No. }\end{array}$ & Soil taxonomy & $\begin{array}{l}\text { Type of soil } \\
\text { sets }\end{array}$ \\
\hline \multirow{15}{*}{$\begin{array}{l}\text { Flood } \\
\text { plain }\end{array}$} & \multirow[t]{4}{*}{ Nile deposits } & \multirow[t]{2}{*}{ Recent Islands } & Recent sand deposits & $I_{1}$ & 1 & \multirow{2}{*}{$\begin{array}{l}\text { Typic } \\
\text { Torripsamment }\end{array}$} & \multirow[t]{2}{*}{ Cons. } \\
\hline & & & Sub-recent sand deposits & $\mathrm{I}_{2}$ & 2 & & \\
\hline & & \multirow[t]{2}{*}{ Sub-recent Islands } & Recent sand deposits & $\mathrm{SI}_{1}$ & 3 & \multirow{2}{*}{$\begin{array}{l}\text { Typic } \\
\text { Torripsamment }\end{array}$} & \multirow[t]{2}{*}{ Cons. } \\
\hline & & & $\begin{array}{l}\text { Sub- recent sand } \\
\text { deposits }\end{array}$ & $\mathrm{Sl}_{2}$ & 4 & & \\
\hline & \multirow[t]{9}{*}{ Basin } & \multirow[t]{2}{*}{ Levees } & Recent sand deposits & $L_{1}$ & 5 & \multirow{2}{*}{$\begin{array}{l}\text { Typic } \\
\text { Torripsamment }\end{array}$} & \multirow[t]{2}{*}{ Cons. } \\
\hline & & & $\begin{array}{l}\text { Sub- recent sand } \\
\text { deposits }\end{array}$ & $L_{2}$ & 6 & & \\
\hline & & \multirow[t]{2}{*}{ Over flow mantle } & Relatively high parts & O.M $M_{1}$ & 7 & Typic Torrifluvent & Cons. \\
\hline & & & Relatively high parts & $\mathrm{O} \cdot \mathrm{M}_{2}$ & 8 & Typic Paleargids & Assoc. \\
\hline & & \multirow[t]{2}{*}{ Over flow basin } & Relatively high parts & $O . B_{1}$ & 9 & Vertic Torrifluvent & Cons. \\
\hline & & & Relatively high parts & $\mathrm{O} \cdot \mathrm{B}_{2}$ & 10 & Typic Natrargids & Assoc. \\
\hline & & \multirow[t]{2}{*}{ Decantation basin } & Relatively high parts & D. $B_{1}$ & 11 & Typic Torrifluvent & Cons. \\
\hline & & & Relatively high parts & D. $B_{2}$ & 12 & Typic Torrifluvent & Cons. \\
\hline & & Turtle backs & Complex & T.B & 13 & $\begin{array}{l}\text { Typic } \\
\text { Torripsamment }\end{array}$ & Cons. \\
\hline & \multirow{2}{*}{$\begin{array}{l}\text { River } \\
\text { terraces }\end{array}$} & \multirow{2}{*}{$\begin{array}{l}\text { Sequence of river } \\
\text { terraces }\end{array}$} & The highest river terraces & $\mathrm{T}_{1}$ & 14 & Vertic Torrifluvent & Cons. \\
\hline & & & The lowest river terraces & $\mathrm{T}_{2}$ & 15 & Vertic Torrifluvent & Cons. \\
\hline
\end{tabular}

Cons. consociation, assoc. association

Table 7 Physical and chemical degradation classes according to the natural factors

\begin{tabular}{|c|c|c|c|c|c|c|c|c|c|c|c|}
\hline \multirow{2}{*}{$\begin{array}{l}\text { Profile } \\
\text { No. }\end{array}$} & \multirow{2}{*}{$\begin{array}{l}\text { Mapping } \\
\text { unit }\end{array}$} & \multicolumn{5}{|c|}{ Physical degradation } & \multicolumn{5}{|c|}{ Chemical degradation } \\
\hline & & $C$ & $S$ & $\mathrm{~T}$ & Value & Class & $C$ & $S$ & $\mathrm{~T}$ & Value & Class \\
\hline 1 & $I_{1}$ & 1.0 & 1.90 & 1 & 0.22 & High & 0.21 & 0.3 & 1 & 0.07 & Slight \\
\hline 2 & $\mathrm{I}_{2}$ & 1.0 & 1.88 & 1 & 0.21 & High & 0.21 & 0.3 & 1 & 0.07 & Slight \\
\hline 3 & $\mathrm{Sl}_{1}$ & 1.0 & 1.83 & 1 & 0.21 & High & 0.21 & 0.2 & 1 & 0.06 & Slight \\
\hline 4 & $\mathrm{Sl}_{2}$ & 1.0 & 1.81 & 1 & 0.21 & High & 0.21 & 0.2 & 1 & 0.06 & Slight \\
\hline 5 & $\mathrm{~L}_{1}$ & 1.0 & 1.80 & 1 & 0.20 & Mod. & 0.21 & 0.1 & 1 & 0.05 & Slight \\
\hline 6 & $\mathrm{~L}_{2}$ & 1.0 & 1.75 & 1 & 0.20 & Mod. & 0.21 & 0.1 & 1 & 0.05 & Slight \\
\hline 7 & $O . M_{1}$ & 1.0 & 0.91 & 1 & 0.10 & Mod. & 0.21 & 0.6 & 1 & 0.10 & Mod. \\
\hline 8 & $\mathrm{O} . \mathrm{M}_{2}$ & 1.0 & 0.90 & 1 & 0.10 & Mod. & 0.21 & 0.5 & 1 & 0.10 & Mod. \\
\hline 9 & $O \cdot B_{1}$ & 1.0 & 0.69 & 1 & 0.07 & Slight & 0.21 & 1 & 1 & 0.21 & High \\
\hline 10 & $\mathrm{O} \cdot \mathrm{B}_{2}$ & 1.0 & 0.67 & 1 & 0.07 & Slight & 0.21 & 1 & 1 & 0.21 & High \\
\hline 11 & D. $B_{1}$ & 1.0 & 0.58 & 1 & 0.05 & Slight & 0.21 & 1.2 & 1 & 0.22 & High \\
\hline 12 & $D \cdot B_{2}$ & 1.0 & 0.51 & 1 & 0.05 & Slight & 0.21 & 1.2 & 1 & 0.22 & High \\
\hline 13 & T.b & 1.0 & 1.90 & 1 & 0.2 & Mod & 0.21 & 0.3 & 1 & 0.07 & Slight \\
\hline 14 & $\mathrm{~T}_{1}$ & 1.0 & 1.45 & 1 & 0.14 & Mod. & 0.21 & 0.3 & 1 & 0.07 & Slight \\
\hline 15 & $\mathrm{~T}_{2}$ & 1.0 & 1.12 & 1 & 0.11 & Mod. & 0.21 & 0.3 & 1 & 0.07 & Slight \\
\hline
\end{tabular}




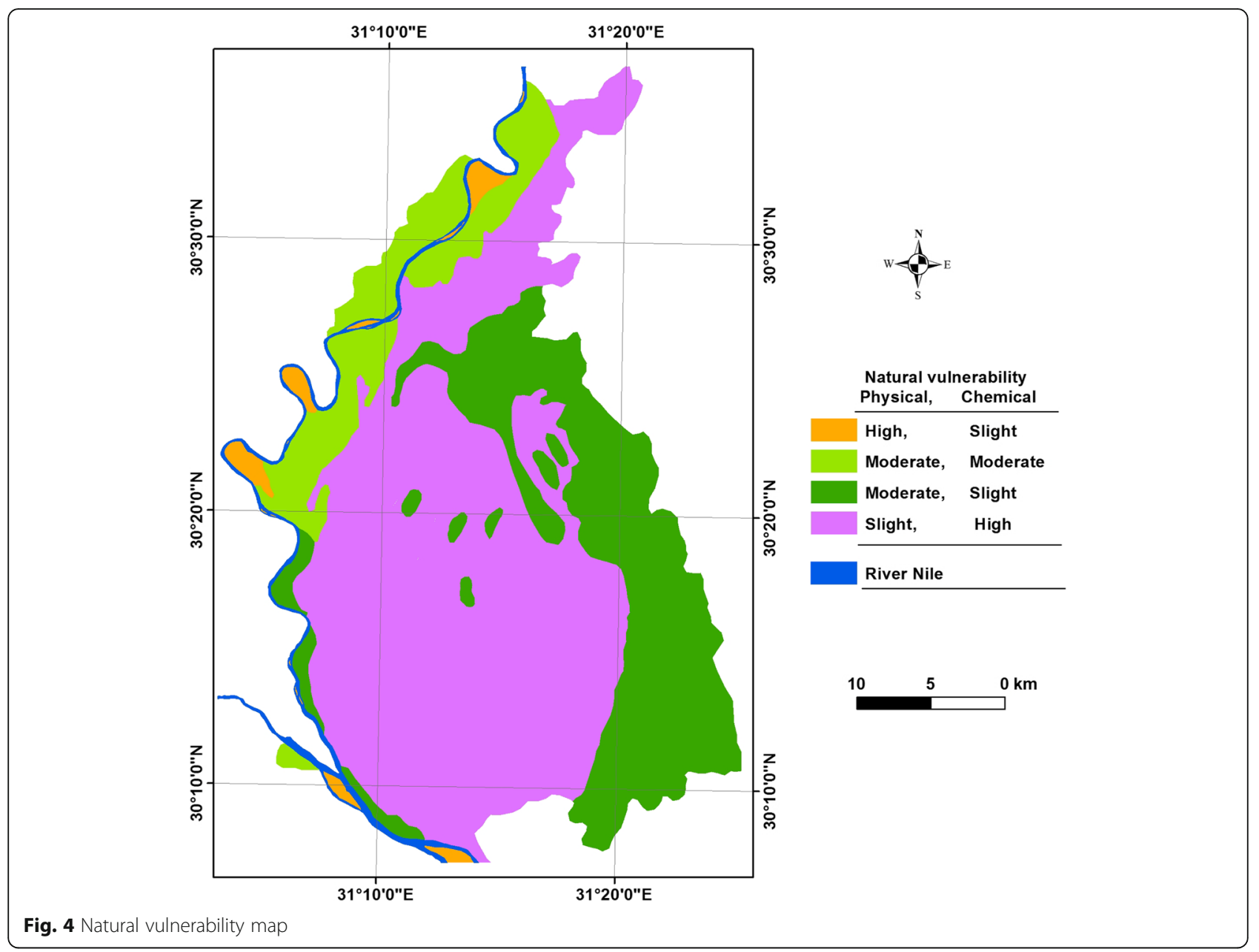

- O.B, Typic Natrargids (Assoc.)-D.B, Typic

Torrifluvent (Cons.)

- T.B, Typic Torripsamment (Assoc.) - T, Vertic Torrifluvent (Cons.)

Table 8 Relative extent (\%) of the natural vulnerability classes in the study area

\begin{tabular}{|c|c|c|c|c|c|c|c|}
\hline \multirow{3}{*}{$\begin{array}{l}\text { Mapping } \\
\text { unit }\end{array}$} & \multirow{3}{*}{$\begin{array}{l}\text { Area } \\
\text { acre }\end{array}$} & \multicolumn{6}{|c|}{ Relative extent \% } \\
\hline & & \multicolumn{3}{|c|}{ Physical degradation } & \multicolumn{3}{|c|}{ Chemical degradation } \\
\hline & & Slight & Moderate & High & Slight & Moderate & High \\
\hline | & 861.39 & 0.2 & 18.0 & 81.8 & 88.5 & 11.4 & 0.1 \\
\hline SI & 1642.76 & 0.9 & 20.9 & 78.2 & 80.6 & 19.2 & 0.2 \\
\hline L & 2116.80 & 2.2 & 79.5 & 18.3 & 79.8 & 19.8 & 0.4 \\
\hline O.M & $20,913.82$ & 1.3 & 75.6 & 23.1 & 1.6 & 80.1 & 18.3 \\
\hline$O . B$ & $39,841.59$ & 78.1 & 21.5 & 0.4 & 0.2 & 23.9 & 75.9 \\
\hline D.B & $70,893.74$ & 83.9 & 16.0 & 0.1 & - & 15.1 & 84.9 \\
\hline T.B & 391.48 & - & 19.9 & 80.1 & - & 8.6 & 91.4 \\
\hline $\mathrm{T}$ & 9991.79 & 8.9 & 76.4 & 14.7 & 79.4 & 20.4 & 0.2 \\
\hline
\end{tabular}

The physiographic and soil map legend of the investigated area is shown in Table 6.

\section{Land degradation assessment Natural vulnerability}

Vulnerability means the potential to be harmed. Natural vulnerability encompasses the conditions determined by physical, social-economic, and environmental processes that increase the susceptibility of a land to the impact of natural hazards (UNISDR 2009). In principle, the agricultural land in Egypt is characterized by being among the most intensive agricultural use systems; it may reach three crop rotations a year according to the Egyptian crop calendar followed. These have contributed to the excessive cultivation of land, with the consequence of poor crop production. This misuse practice has not only negative effect on areas of the fertile land but also decrease the overall agro-exports from vegetables and fruits and hence add a lot of burden on the Egyptian economy.

The natural vulnerability and its relative extent percentage of different mapping units in the area under 
Table 9 Changes of the main land characteristics

\begin{tabular}{|c|c|c|c|c|c|c|c|c|c|}
\hline \multirow[t]{2}{*}{$\begin{array}{l}\text { Profile } \\
\text { No. }\end{array}$} & \multirow[t]{2}{*}{$\begin{array}{l}\text { Mapping } \\
\text { unit }\end{array}$} & \multicolumn{2}{|c|}{ Depth of water table level (cm) } & \multicolumn{2}{|c|}{$\begin{array}{l}\text { Bulk density }{ }^{a} \\
\mathrm{~g} / \mathrm{cm}^{3}\end{array}$} & \multicolumn{2}{|c|}{$E C^{a} d s / m$} & \multicolumn{2}{|c|}{ ESPa $\%$} \\
\hline & & 1967 & 2017 & 1967 & 2017 & 1967 & 2017 & 1967 & 2017 \\
\hline 1 & $l_{1}$ & 100 & 65 & 1.10 & 1.12 & 2.62 & 4.31 & 8.7 & 10.1 \\
\hline 2 & $\mathrm{l}_{2}$ & 110 & 80 & 1.10 & 1.13 & .3 .24 & 4.00 & 9.0 & 11.3 \\
\hline 3 & $\mathrm{Sl}_{1}$ & 100 & 70 & 1.13 & 1.14 & 3.00 & 4.21 & 8.4 & 10.2 \\
\hline 4 & $\mathrm{Sl}_{2}$ & 100 & 80 & 1.15 & 1.16 & 3.72 & 5.10 & 8.1 & 9.6 \\
\hline 5 & $\mathrm{~L}_{1}$ & 110 & 75 & 1.12 & 1.15 & 3.18 & 6.19 & 9.2 & 11.3 \\
\hline 6 & $\mathrm{~L}_{2}$ & 100 & 65 & 1.14 & 1.15 & 4.00 & 6.18 & 9.1 & 11.2 \\
\hline 7 & $\mathrm{O} . \mathrm{M}_{1}$ & 120 & 100 & 1.30 & 1.35 & 5.31 & 9.21 & 9.0 & 15.0 \\
\hline 8 & $\mathrm{O} . \mathrm{M}_{2}$ & 130 & 100 & 1.27 & 1.31 & 6.00 & 10.41 & 10.6 & 15.8 \\
\hline 9 & $\mathrm{O} \cdot \mathrm{B}_{1}$ & 120 & 90 & 1.29 & 1.35 & 6.49 & 11.23 & 15.0 & 16.1 \\
\hline 10 & $\mathrm{O} \cdot \mathrm{B}_{2}$ & 120 & 100 & 1.26 & 1.29 & 7.24 & 10.17 & 15.9 & 19.8 \\
\hline 11 & D. $B_{1}$ & 110 & 90 & 1.24 & 1.42 & 5.14 & 9.16 & 15.8 & 19.3 \\
\hline 12 & D. $B_{2}$ & 120 & 70 & 1.30 & 1.46 & 6.25 & 9.00 & 15.4 & 17.9 \\
\hline 13 & T.B & 150 & 125 & 1.16 & 1.17 & 3.90 & 6.91 & 14.5 & 15.3 \\
\hline 14 & $\mathrm{~T}_{1}$ & 120 & 100 & 1.18 & 1.19 & 2.81 & 4.83 & 9.4 & 11.4 \\
\hline 15 & $\mathrm{~T}_{2}$ & 110 & 95 & 1.15 & 1.18 & 3.19 & 5.20 & 7.8 & 10.1 \\
\hline
\end{tabular}

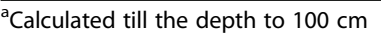

investigation are illustrated in Table 7 and Fig. 4. The obtained data elucidated that soil of the map units (I, SI, L, O.M, T.B, and T) have a physical degradation ranging from moderate to high risk. In turn, the physical high risk degradation type is related to high content of silt fraction and low percentage of soil organic matter. Nevertheless, soils of (O.B and D.B) have a slight physical degradation related to low content of silt and high percentage of organic matter. In addition, the map units (I, SI, L, O.M, T.B, and T) exposed a chemical degradation risk ranging from slight to moderate. Moreover, units (O.B and D.B) exhibit a high chemical degradation risk due to high evapotranspiration value compared with the actual received amount of precipitation and irrigation water. The relative extent percentage (\%) of the natural vulnerability classes are presented in Table 8 .

Table 10 Land degradation rates in the different mapping units of the study area

\begin{tabular}{|c|c|c|c|c|c|}
\hline Profile No. & Mapping unit & Water logging & Compaction & Salinization & Alkalization \\
\hline 1 & 11 & 2 & 1 & 1 & 1 \\
\hline 2 & 12 & 1 & 1 & 1 & 1 \\
\hline 3 & SI1 & 1 & 1 & 1 & 1 \\
\hline 4 & $\mathrm{SI} 2$ & 1 & 1 & 1 & 1 \\
\hline 5 & L1 & 2 & & & \\
\hline 6 & L2 & 1 & 1 & 1 & 1 \\
\hline 7 & O.M1 & 1 & 1 & 1 & 1 \\
\hline 8 & O.M2 & 1 & 1 & 1 & 1 \\
\hline 9 & O.B1 & 1 & 1 & 1 & 1 \\
\hline 10 & O.B2 & 1 & 1 & 1 & 1 \\
\hline 11 & D.B1 & 1 & 1 & 1 & 1 \\
\hline 12 & D.B2 & 1 & 1 & 1 & 1 \\
\hline 13 & T.B & 1 & 1 & 1 & 1 \\
\hline 14 & T1 & 1 & 1 & 1 & 1 \\
\hline 15 & T2 & 1 & 1 & 1 & 1 \\
\hline
\end{tabular}


Table 11 Relative extent (\%) of the land degradation types

\begin{tabular}{|c|c|c|c|c|c|c|c|c|c|c|c|c|c|}
\hline \multirow{2}{*}{$\begin{array}{l}\text { Main } \\
\text { mapping } \\
\text { unit }\end{array}$} & \multirow{2}{*}{$\begin{array}{l}\text { Area } \\
\text { (acres) }\end{array}$} & \multicolumn{3}{|c|}{ Water logging (depth of water table $(\mathrm{cm})$} & \multicolumn{3}{|c|}{ Compaction (bulk density) $\left(\mathrm{g} / \mathrm{cm}^{3}\right)$} & \multicolumn{3}{|c|}{ Salinization EC (dS/m) } & \multicolumn{3}{|c|}{ Alkalization (ESP \%) } \\
\hline & & $>100$ & $100-75$ & $75-50$ & $<1.2$ & $1.2-1.35$ & $1.35-1.50$ & $<4$ & $4-8$ & 8.16 & $<15$ & $15-25$ & $25-35$ \\
\hline I & 861.39 & 4.41 & 53.81 & 41.78 & 60.12 & 39.88 & - & 61.29 & 38.71 & - & 89.16 & 10.84 & - \\
\hline SI & 1642.76 & 8.23 & 59.13 & 32.64 & 51.43 & 48.57 & - & 70.82 & 29.18 & - & 90.21 & 9.79 & - \\
\hline L & 2116.80 & 19.80 & 51.03 & 29.17 & 54.90 & 45.10 & - & 8.19 & 90.58 & 1.23 & 82.14 & 17.86 & - \\
\hline O.M & $20,913.82$ & 39.22 & 58.09 & 2.69 & 32.70 & 59.13 & 8.17 & 4.82 & 63.58 & 31.60 & 77.21 & 22.79 & - \\
\hline$O . B$ & $39,841.59$ & 42.17 & 54.65 & 3.18 & 21.16 & 64.02 & 14.82 & 1.20 & 56.98 & 41.82 & 58.8 & 41.2 & - \\
\hline D.B & $70,893.74$ & 26.17 & 62.54 & 11.29 & - & 77.84 & 22.16 & 0.80 & 50.02 & 49.18 & 46.19 & 53.81 & - \\
\hline T.B & 391.48 & 75.84 & 24.16 & - & 51.62 & 48.38 & - & 65.29 & 34.51 & 0.20 & 83.31 & 16.69 & - \\
\hline $\mathrm{T}$ & 9991.79 & 76.28 & 23.72 & - & 54.11 & 45.89 & - & 61.11 & 38.49 & 0.40 & 80.26 & 19.74 & - \\
\hline
\end{tabular}

\section{Human-induced land degradation}

Definitely, human-induced land degradation is an actual increasing problem. Growth of population, agricultural pressure, unsustainable management of natural resources, as well as increasing amounts of harmful chemicals added to the environment all lead to severe land degradation. This phenomenon has to be considered from different prospective, e.g., agrarian, economic, cultural, and social conditions. The GLASOD approach is a first attempt to generate real maps on the status of human-induced land degradation (UNEP 1991).

The human-induced land degradation in the studied areas were assessed throughout the identification of rate, degree, relative extent, causative factors, and severity level of each type of land degradation (water logging, compaction, salinization, and alkalization) for the different mapping units as follow.

\section{Land degradation rate}

The rate of land degradation was estimated though a tabular comparison of the main land characteristics in (1967) and (2017) (Table 9). The degradation rate for each mapping unit was classified to slight as shown in Table 10. The data revealed that the rate of salinization, alkalization, and compaction are slight. The annual increase of the soil electrical conductivity (ECe), exchangeable sodium percentage (ESP), and bulk density were reached to $(0.1 \mathrm{dS} / \mathrm{m}),(0.2 \%)$, and $\left(0.01 \mathrm{~g} / \mathrm{cm}^{3}\right)$ respectively. In the study area, the rate of water logging is slight to moderate as the maximum increase of water table is $(1.7 \mathrm{~cm} /$ year $)$.

\section{Degree of land degradation}

The measured values of ECe, ESP, bulk density and water table depth are presented in range between (4.00-

Table 12 Causative factors of human-induced land degradation types

\begin{tabular}{|c|c|c|c|c|c|}
\hline Profile No. & Mapping unit & Water logging & Compaction & Salinization & Alkalization \\
\hline 1 & 11 & $\mathrm{i} / \mathrm{d} / \mathrm{o}$ & - & - & - \\
\hline 2 & 12 & $\mathrm{i} / \mathrm{d} / \mathrm{o}$ & - & - & o \\
\hline 3 & SI1 & $\mathrm{i} / \mathrm{d} / \mathrm{O}$ & - & - & - \\
\hline 4 & $\mathrm{SI} 2$ & $\mathrm{i} / \mathrm{d} / \mathrm{o}$ & o & - & o \\
\hline 5 & L1 & $\mathrm{i} / \mathrm{d} / \mathrm{o}$ & o & o & - \\
\hline 6 & L2 & $\mathrm{i} / \mathrm{d} / \mathrm{o}$ & o & o & o \\
\hline 7 & O.M1 & i/o & $\mathrm{m} / \mathrm{o}$ & mi & mi \\
\hline 8 & $\mathrm{O} . \mathrm{M} 2$ & i/o & $\mathrm{m} / \mathrm{o}$ & mi & mi \\
\hline 9 & O.B1 & i/o & $\mathrm{m} / \mathrm{o}$ & mi & mi \\
\hline 10 & O.B2 & i/o & $\mathrm{m} / \mathrm{o}$ & mi & mi \\
\hline 11 & D.B1 & i/o & $\mathrm{m} / \mathrm{o}$ & $\mathrm{mi} / \mathrm{o}$ & $\mathrm{mi} / \mathrm{o}$ \\
\hline 12 & D.B2 & i/o & $\mathrm{m} / \mathrm{o}$ & mi/o & $\mathrm{mi} / \mathrm{o}$ \\
\hline 13 & T.B & - & - & mi & mi \\
\hline 14 & T1 & - & - & - & - \\
\hline 15 & $\mathrm{~T} 2$ & - & - & o & o \\
\hline
\end{tabular}

Where i: over irrigation, mi: poor management of irrigation scheme, $\mathrm{m}$ : improperly timed used of heavy machinery, $\mathrm{d}$ : human intervention in natural drainage, o: other activities which include shorting of the follow periods and the absence of conservation measurements 


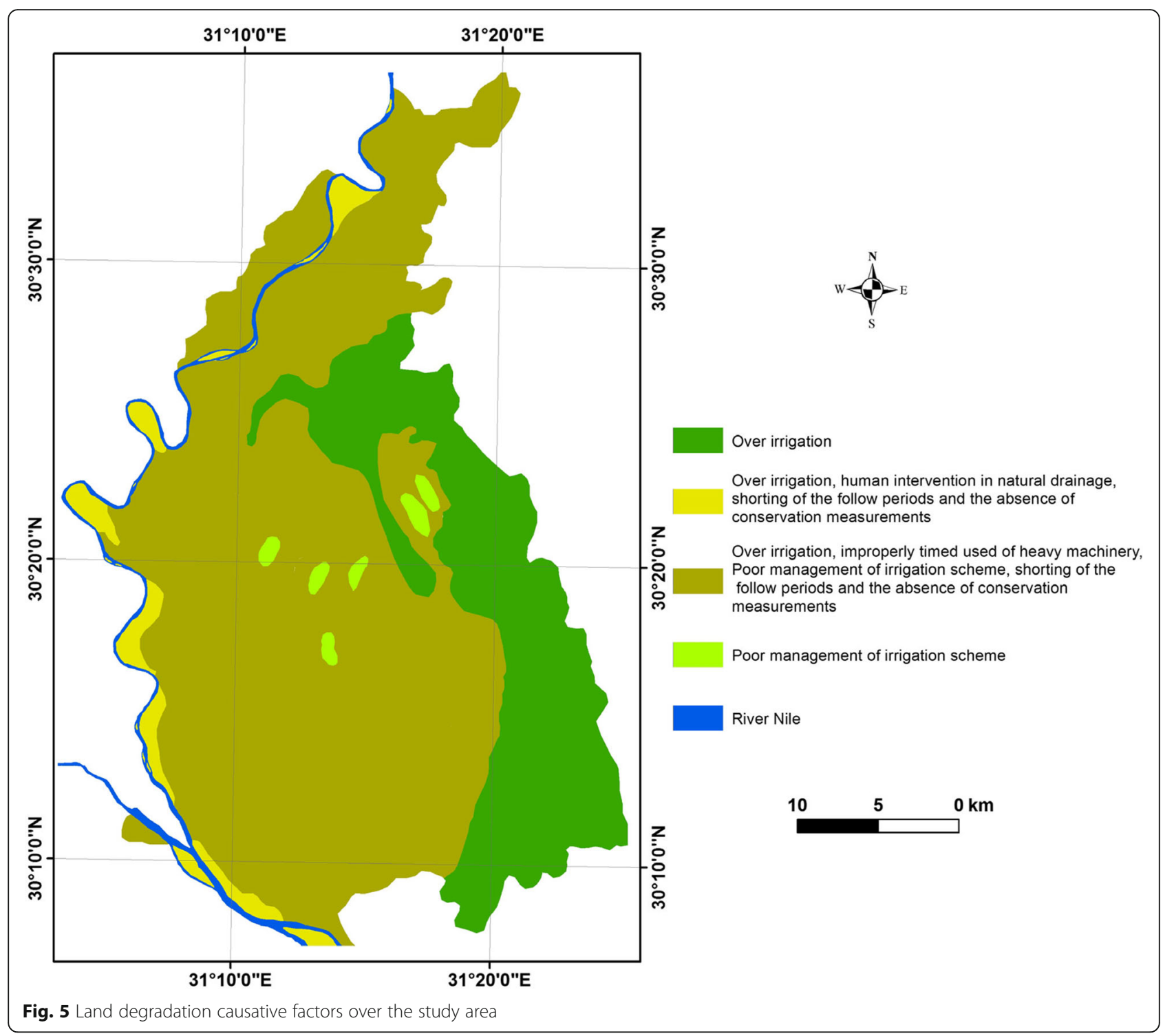

$11.23 \mathrm{dS} / \mathrm{m}),(9.6-19.8 \%),(1.123-1.46 \mathrm{~g} / \mathrm{cm} 3)$, and $(65-$ $125 \mathrm{~cm}$ ) in the order already mentioned. The hazards of land degradation types differ from low to moderate.

\section{Relative extent of land degradation}

The relative extent percentage of each type of human induced land degradation was estimated based upon the correlation between land physiography and soils in the various mapping units as illustrated in Table 11.

\section{Discussion}

Interpretation and identification of degraded areas by analysis of satellite image data and modeling are considered initial steps to address land degradation issues in Qalyubia Governorate. The GLASOD model adapted for this research is competent in terms of its flexibility; it allows for modification to accommodate indicators of land degradation.

\section{Causative factors of human-induced land degradation}

In the area under investigation, the main causative factors of human-induced land degradation types are mentioned in Table 12 and Fig. 5. Taken into account the environmental factors and processes that would occur without human interference, the soil degradation is resulted when soils are not properly managed, misused, or inefficient utilized. The main types of human-induced land degradation are salinization, alkalization, soil compaction, and water logging; these types are affected as follow:

- Salinization and alkalization: the human-induced salinization and alkalization could result from three 
Table $\mathbf{1 3}$ Land degradation severity level in the study area

\begin{tabular}{|c|c|c|c|c|c|c|c|c|c|c|c|c|c|}
\hline \multirow{2}{*}{$\begin{array}{l}\text { Profile } \\
\text { No. }\end{array}$} & \multirow{2}{*}{$\begin{array}{l}\text { Mapping } \\
\text { unit }\end{array}$} & \multicolumn{3}{|c|}{ Water logging } & \multicolumn{3}{|c|}{ Compaction } & \multicolumn{3}{|c|}{ Salinization } & \multicolumn{3}{|c|}{ Alkalization } \\
\hline & & $D$ & $E$ & $S L$ & D & $E$ & $S L$ & $D$ & $E$ & SL & D & $E$ & SL \\
\hline 1 & $I_{1}$ & 3 & 4 & 3.4 very high & 1 & 5 & 1.5 low & 1 & 5 & 1.5 low & 1 & 5 & 1.5 low \\
\hline 2 & $\mathrm{I}_{2}$ & 3 & 3 & 3.3 high & 1 & 5 & 1.5 low & 1 & 5 & 1.5 low & 2 & 2 & 2.2 moderate \\
\hline 3 & $\mathrm{SI}_{1}$ & 3 & 4 & 3.4 very high & 1 & 5 & 1.5 low & 1 & 5 & 1.5 low & 1 & 5 & 1.5 low \\
\hline 4 & $\mathrm{Sl}_{2}$ & 3 & 3 & 3.3 high & 1 & 5 & 1.5 low & 2 & 2 & 2.2 moderate & 2 & 2 & 2.2 moderate \\
\hline 5 & $L_{1}$ & 3 & 4 & 3.4 very high & 1 & 5 & 1.5 low & 2 & 4 & 2.4 high & 1 & 5 & 1.5 low \\
\hline 6 & $\mathrm{~L}_{2}$ & 3 & 3 & 3.3 high & 1 & 5 & 1.5 low & 2 & 4 & 2.4 high & 2 & 2 & 2.2 moderate \\
\hline 7 & $O . M_{1}$ & 2 & 2 & 2.2 moderate & 2 & 4 & 2.4 high & 2 & 4 & 2.4 high & 2 & 2 & 2.2 moderate \\
\hline 8 & $\mathrm{O} . \mathrm{M}_{2}$ & 2 & 2 & $\begin{array}{l}2.2 \\
\text { moderate }\end{array}$ & 2 & 4 & $\begin{array}{l}2.4 \\
\text { high }\end{array}$ & 2 & 4 & $\begin{array}{l}2.4 \\
\text { high }\end{array}$ & 1 & 5 & $\begin{array}{l}1.5 \\
\text { low }\end{array}$ \\
\hline 9 & $O \cdot B_{1}$ & 2 & 4 & 2.4 high & 2 & 4 & 2.4 high & 2 & 4 & 2.4 high & 2 & 4 & 2.4 high \\
\hline 10 & $\mathrm{O} \cdot \mathrm{B}_{2}$ & 2 & 4 & 2.4 high & 2 & 4 & 2.4 high & 2 & 4 & 2.4 high & 2 & 4 & 2.4 high \\
\hline 11 & D. $B_{1}$ & 2 & 4 & 2.4 high & 2 & 5 & 2.5 very high & 2 & 5 & 2.5 very high & 2 & 5 & 2.5 very high \\
\hline 12 & D. $B_{2}$ & 2 & 4 & 2.4 high & 2 & 5 & 2.5 very high & 2 & 5 & 2.5 very high & 2 & 5 & 2.5 very high \\
\hline 13 & T.B & 1 & 5 & 1.5 low & 1 & 5 & 1.5 low & 2 & 2 & 2.2 moderate & 2 & 2 & 2.2 moderate \\
\hline 14 & $\mathrm{~T}_{1}$ & 1 & 5 & 1.5 low & 1 & 5 & 1.5 low & 2 & 4 & 2.4 high & 1 & 5 & 1.5 low \\
\hline 15 & $\mathrm{~T}_{2}$ & 1 & 5 & 1.5 low & 1 & 5 & 1.5 low & 2 & 4 & 2.4 high & 1 & 5 & 1.5 low \\
\hline
\end{tabular}

$D$ degree, $E$ extent, $S L$ severity level

causes. First, it can be the result of poor management of irrigation schemes. A high salt content of the irrigation water or too little attention given to the drainage status of irrigated field that can easily lead to rapid salinization and/or alkalization problems. This type of salt accumulation mainly occurs under arid and semi-arid condition. Second, salinization and/or alkalization will occur if sea water or fossil saline ground water bodies intrude onto agricultural lands and intrude the groundwater reserves and reservoirs of good quality. This sometimes happens in the coastal

Table 14 Land degradation status in the different mapping unit

\begin{tabular}{|c|c|}
\hline Mapping unit & Land degradation status \\
\hline I & (Pw i/d/o 3,4) (Ca o 2,2) \\
\hline $\mathrm{SI}$ & $(\mathrm{Pw} \mathrm{i} / \mathrm{d} / \circ \mathrm{3}, 4)(\mathrm{Cs} \circ 2,2)(\mathrm{Ca} \circ 2,2)$ \\
\hline L & $(\mathrm{Pw} \mathrm{i} / \mathrm{d} / \circ \mathrm{3,3})(\mathrm{Cs} \circ 2,4)(\mathrm{Ca} \circ 2,2)$ \\
\hline O.M & $(\mathrm{Pw} \mathrm{i} / \mathrm{o} 2,2)(\mathrm{Pc} \mathrm{m} / \mathrm{o} 2,4)(\mathrm{Cs} \mathrm{mi} 2,4)(\mathrm{Ca} \mathrm{mi} 2,4)$ \\
\hline$O . B$ & $(\mathrm{Pw} \mathrm{i} / \mathrm{o} 2,4)(\mathrm{Pc} \mathrm{m} / \mathrm{c} \mathrm{2,4})(\mathrm{Cs} \mathrm{mi} 2,4)(\mathrm{Ca} \mathrm{mi} 2,4)$ \\
\hline D.B & $(\mathrm{Pw} \mathrm{i} / \mathrm{o} 2,4)(\mathrm{Pc} \mathrm{m} / \mathrm{o}$ 2.5) (Cs mi/o 2,5) (Ca mi 2,5) \\
\hline T.B & (Cs mi 2,2) (Ca mi 2,2) \\
\hline $\mathrm{T}$ & $(\mathrm{Cs} \circ 2,4)$ \\
\hline
\end{tabular}

The first two letters = degradation types as, $P w$ physical degradation/water logging, Pc physical degradation/soil compaction, Cs chemical degradation/ salinization, $\mathrm{Ca}$ chemical degradation/alkalization

The following one or two letters = causative factors as, I over irrigation, $d$ human intervention in natural drainage, $m$ improperly time use of heavy machinery, mi poor management of irrigation scheme, $o$ other activities The first digit = degree of land degradation; the second digit = relative extent of degradation regions with an excessive use of groundwater, but can also occur in closed basin with aquifers of different salt content. Worth to mention that a third type happens where human activities lead to an increase in evapo-transpiration of soil moisture in land of high salt-containing parent materials or with saline ground water. In the study area of Qalyubia governorate, the causes of soil salinization could be due to the interactions of various factors: limited available supply of irrigation water, shallow groundwater table, water salinity, poor drainage conditions, parent material, topography, poor management, and climatic factors (high temperature, high evaporation rate, and humidity action) (Fig. 5). These factors were captured in questionnaires administered during the field study.

- Compaction: this mainly occurs in the soils with a low physical structural stability, under the improper human activities. In the studied areas, soil compaction resulted from inexpedient management and improperly timed use of heavy machinery, misapply of irrigation, absence of conservative measurements, shortage of the fallow period, and an excessive application of harmful chemical fertilizers. This is a major observed degradation characteristic in the study area, which in return would decrease the yield and compact the soil, making it difficult to till the land. As the soil becomes compacted, 


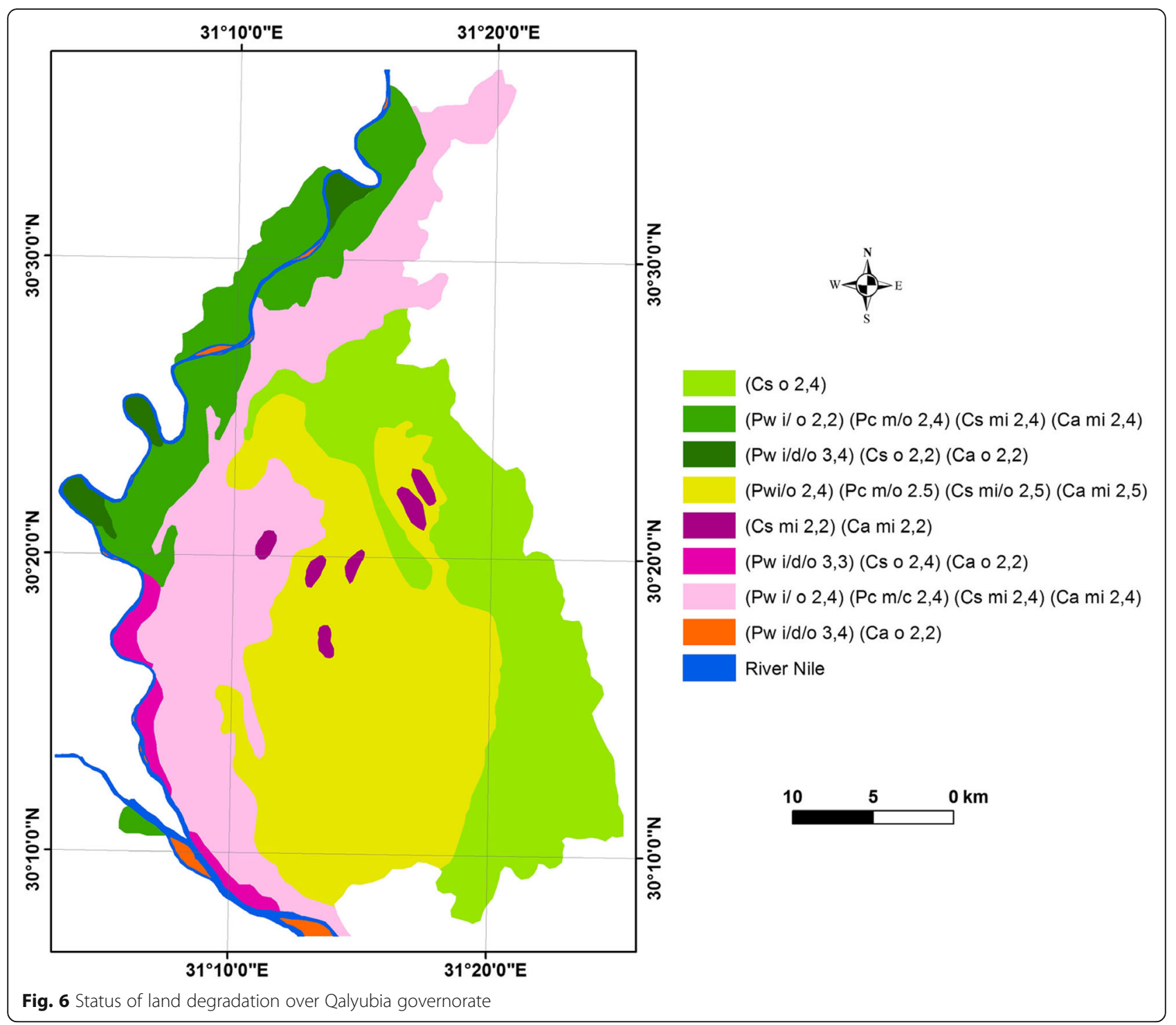

aeration becomes limited; hence, such lands become less suitable for farming.

- Water logging: human intervention in the natural drainage systems by the misuse of irrigation water quality may lead to flooding especially in heavy clay soils. Over irrigation, inefficient drainage system, and destruction of subsurface drainage networks (in some parts) are the main causes of water logging in the considered areas.

\section{Severity level}

The severity level of land degradation is indicated by a combination of the degradation degree and relative extent of degradation types (Table 13).

\section{Status of land degradation}

The obtained data of degradation rate, degree, extent, causative factors, and the severity levels in the different mapping units of the studied area are shown in Table 14 and Fig. 6.

\section{Conclusion}

Agricultural land experience rapid changes due to natural and manmade factors. Monitoring these changes is essential for sustainable planning, resource management, and updating geospatial information systems. In general, the agricultural soils in Qalyubia governorate are characterized by quite good soil productivity. Soil units of the study area have a low degradation rate for different types of human-induced factors due to the less change in land characteristics in the last 50 years. This is obtained from 
monitoring changes in land characteristics during the time period of 1967 and 2017. The integration of remote sensing data and GIS utilities would provide a more precise information on observing the nature and spatial distribution of land use/cover changes and in elaborating the degradation degree. In regard to the present values of soil depth, bulk density, electric conductivity ECe, and exchangeable sodium percentage ESP, the soil units are threatening by a low to moderate degree of water logging, compaction, salinity, and alkalinity as a result of active degradation processes. The moderate values of these types are due to the over irrigation system applied, poor management of irrigation scheme, improper use of heavy machinery, absence of conservation measurements, excessive farm application of harmful chemical fertilizers, and other cultural factors. The severity level of the different degradation types in the targeted soils are indicated as low to very high level. Mitigation of soil sealing by use of diverse media would assist in increase people's awareness of the seriousness of land degradation and implications on agricultural land.

\section{Acknowledgements}

Not applicable.

\section{Funding}

The funding resources mainly come through the contribution of both soil and water departments in the Faculty of Agric., Cairo Uni., in cooperation with the Land and Water Technologies Dept., Arid Lands Cultivation Research Institute, City of Scientific Research and Technological Applications, Borg Al-Arab city.

\section{Availability of data and materials}

The datasets used and/or analyzed during the current study are available from the corresponding author on reasonable request. All figures, maps, and tables generated during this study are included in this published article.

\section{Authors' contributions \\ Both authors contribute to the conception, design of the work; the acquisition, analysis, interpretation of data; the creation of new software used in the work; and have drafted the work or substantively revised it. Both authors have approved the submitted version (and any substantially modified version that involves the author's contribution to the study). Both authors have agreed to be personally accountable for the author's own contributions and to ensure that questions related to the accuracy or integrity of any part of the work, even ones in which the author was not personally involved, are appropriately investigated, resolved, and the resolution documented in the literature. Both authors read and approved the final manuscript.}

\section{Ethics approval and consent to participate}

Not applicable.

\section{Consent for publication}

Not applicable.

\section{Competing interests}

The authors declare that they have no competing interests.

\section{Publisher's Note}

Springer Nature remains neutral with regard to jurisdictional claims in published maps and institutional affiliations.

\section{Author details}

Soils Science Department, Faculty of Agriculture, Cairo University, Giza, Egypt. 'Land and Water Technologies Department, Arid Lands Cultivation Research Institute, City of Scientific Research and Technological Applications (SRTA-City), Borg Al-Arab, Alexandria, Egypt.

Received: 8 January 2019 Accepted: 25 March 2019

Published online: 25 April 2019

\section{References}

ASRT (1982) Soil map of Egypt, final report. Academy of Scientific Research and Technology (ASRT), Cairo

Ayoub AT (1991) An assessment of human induced soil degradation in Africa. U. N. environmental program, Nairobi, Kenya, Second Soil Sci. conf, Cairo

Baylis K, Jolejole M, Lipper L (2012) Land degradation's implications on agricultural value of production in Ethiopia: a look inside the bowl. Presentation Papers at the International Association of Agricultural Economists (IAAE) Triennial Conference, Foz do Iguacu

Dobos E, Norman B, Bruee W, Luca M, Chris J, Erika M (2002) The use of DEM and satellite images for regional scale soil database. Proceedings of the 17th World Congress of Soil Science, Bangkok

Dregn HE (2002) Land degradation in the drylands. Arid Land Res Manag 16(2): 99-132

Dwivedi RS, Sreenivas K, Ramana KV (1999) Inventory of salt affected soils and water-logged areas: a remote sensing approach. Int J Remote Sens 20(8): 1589-1599

Egyptian Meteorological Authority. Climatic Atlas of Egypt. Published report, Ministry of Transport, Arab Republic of Egypt: 2016

Elberson GWW, Catalan R (1987) Portable computer in physiographic soil survey. Proc. Intemat soil Sci., Cong, Homburg

El-Kassas M (1999) Desertification and land degradation in arid regions. Alla, ElMorfa, Kuwait (Arabic), p 258

FAO/UNEP. Methodology for assessing soil degradation. 2527, Rome, Italy; 1978

FAO/UNEP (1979) A Provisional methodology for degradation assessment. FAO, Rome, p 48

ITT. ITT corporation ENVI 5.1 software. 1133 Westchester Avenue, White Plains, NY 10604, USA; 2009

Johnson DL, Lewis LA (2007) Land degradation: creation and destruction. Rowman and Littlefield, Lanham, DM, Boulder, New York, Toronto, Oxford.

Lillesand TM, Kiefer RW (2007) Remote sensing and image interpretation, 5th edn. Wiley, New York, p 820 Academic

Page AL, Miller RH, Keeney DR (1982) Methods of soil analysis (part 2)—chemical and microbiological properties, 2nd edn. Amer. Soc. of Agron, Madison

Richard LA. Diagnosis and improvement of saline and alkali soils. U.S. Dept. of Agric. HandBook, 1954, No. 60

RISW (1967) Soil survey of El-Kaluibiea Governorate. Report No. 155, Research Institute of Soils and Water (RISW), Cairo

Said R (1993) The river Nile geology and hydrology and utilization. Britain, Pergamon Press, Oxford, p 320

Soil Survey Staff (2014) Keys to soil taxonomy, 12th edn. USDA-Natural Resources Conservation Service, Washington, DC

Sun B, Li Z, Gao Z, Guo Z, Wang B, Hu X, Bai L (2017) Grassland degradation and restoration monitoring and driving forces analysis based on long time-series remote sensing data in XilinGol league. Acta Ecol Sin 37(4):219-228

UNCCD (1994) United Nations convention to combat desertification in those countries experiencing serious drought and/or desertification, particularly in Africa. UN, Paris

UNCCD, (2002) Global Alarm: Dust and Sandstorms from the World's Drylands, Asia Regional Coordinating Unit, Secretariat of the United Nations Convention to Combat Desertification (UNCCD-CRIC1), Bangkok.

UNCCD (2013) Economic and Social impacts of desertification, land degradation and drought. White Paper I. UNCCD 2nd Scientific Conference of United Nations Convention to Combat Desertification, prepared with the contributions of an international group of scientists. Available from: http:// 2sc.unccd.int (accessed 26 March 2013.), ISBN 978-92-95043-66-4, Bonn, Germany.

UNEP Staff. Global assessment of soil degradation, UNEP UN GLASOG Project: 1991

United Nations International Strategy for Disaster Reduction (UN/ISDR) (2009) UNISDR terminology on disaster risk reduction. UN/ISDR, Geneva 
US Soil Survey Staff. Soil survey field and laboratory methods manual. Soil survey investigations report no. 51, version 2.0.; 2014. R. Burt and Soil survey staff (ed.). U.S. Department of Agriculture, Natural Resources Conservation Service Wim G, El-Hadji M (2002) Causes, general extent and physical consequence of land degradation in arid, semi-arid and dry sub humid areas. Forest conservation and natural resources, forest dept. FAO, Rome

Zink JA, Valenzuala (1990) Soil geographic database: structure and application examples. ITC J. vol. 3. ITC, Enschede

Submit your manuscript to a SpringerOpen ${ }^{\odot}$ journal and benefit from:

- Convenient online submission

- Rigorous peer review

- Open access: articles freely available online

- High visibility within the field

- Retaining the copyright to your article

Submit your next manuscript at $\boldsymbol{\wedge}$ springeropen.com 